how linked to costs. Brezhnev's reforms of the 1960 s failed, he says, because they were exclusively economic.

According to Belykh, the immediate economic goal of perestroika, that of moderating consumer subsidies and allowing salaries to rise in compensation, has been on the planners' agenda for well over a decade. Of the logic, he says, there is no doubt, but the speed of change remains in doubt.

Aganbegyan has been saying that an economic relationship between costs and prices should be in place by 1991 , but Belykh believes that may not be feasible. The immediate difficulty is that Soviet economic statistics are inadequate for an accurate calculation of the trade-off, "It would be unwise to say that our statistics are in an exceptionally good condition."

The extent to which the lack of statistics may cramp Mr Gorbachev's economic reforms may not yet be fully appreciated in the West or even in the Kremlin.

Although the Soviet government has access to a wealth of data about the production of goods of different kinds, there is no means of telling how people's patterns of consumption would change if prices changed. In a capitalist economy, this would not matter; the market would bring equilibrium. The danger, in a planned economy is that ignorance may breed inaction.

Belykh is also open-minded about the

\section{Superconductivity catches Pravda's eye}

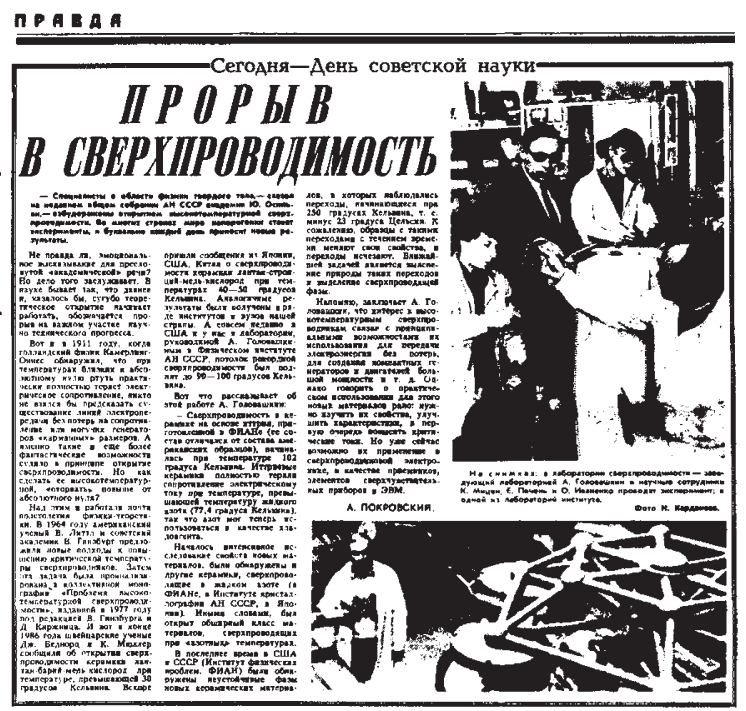

likely consequences of the process of democratization, the election of factory and other managers; "the proof of the pudding is in the eating". If the new system does not work, "we'll have to find another", he says. Nobody can tell what the future holds.

But there is one certainty, in Belykh's opinion: the Soviet Union will never countenance unemployment. But it may at some stage be prepared not to pay high wages to those who do not wish to work, allowing only the productive to share in rising prosperity. Some would say that is a prescription for a welfare state Britishstyle (circa 1968).

Meanwhile, it seems that academic economists are being consulted again by government at all levels. Belykh believes, moreover, that he and his colleagues have a great deal to contribute. The trouble, it seems, is that the pace of change dictated by political considerations may be too quick.

\section{Fiscal facts}

\section{Money means more to capitalists}

Foreigners, the Soviet term for people from elsewhere, should beware of the Soviet concept of money and of the frequently arbitrary values attached to it.

At the official counters, $£ 1$ will buy 1.05 rubles; $\$ 1$ will buy 0.65 rubles or 65 kopeks. But the equivalence is entirely artificial. One can travel $30 \mathrm{~km}$ on the Moscow metro for 15 kopeks, buy a decent breakfast at a hotel buffet for about a ruble or a good seat at the ballet for less than 3 rubles. Domestic air travel is cheap (100 rubles will take a person from one end of the Soviet Union to the other) but tickets hard to purchase; ordinary travellers are allocated seats only when official travellers and tourists (who pay more) have been accommodated.

But some things cost more than elsewhere. International telephone calls to a nearby country such as Britain seem to cost about six times the external rate, and Russian vodka is about the same price in Moscow foreign currency shops as in highly taxed Britain.

Part of the explanation is the Soviet Union's way of socialism. The necessities of life are sold to Soviet citizens at subsidized prices (to which foreigners are properly denied access by an artificially high exchange rate), but luxuries are charged for through the nose, so only foreigners can afford them.

That the exchange rates are artificial is tacitly acknowledged by the procedure under which Soviet citizens with foreign earnings, say from authorship, are allowed either to keep them in a special bank account against future foreign journeys or to convert them, at a ruble rate of 4.6:1, into 'checks' used for the purchase of luxury goods. The checks are convertible (but illegally) into paper rubles at the ratio of $1.7: 1$, suggesting a 'market' conversion rate of 8 rubles to $£ 1$ or thereabouts.

The other side of this coin is that employment is also rewarded cheaply. Wages and salaries are uniformly low. Moscow bus-drivers now earn 350 rubles a month, more than twice as much as 'junior scientific workers' (people with the Soviet equivalent of a PhD at the beginning of their careers). Senior scientists with a BSc may earn 500 rubles a month. Members of the academy earn an extra 500 rubles on that account and a further 150 rubles a month if they become members of the academy's praesidium.

If the objective were simply to match low prices with low salaries, nobody would complain. What Soviet citizens do complain about is that there is little in the shops they want to buy, while services (such as restaurant meals) are almost equally 'unavailable'. The result is that many people have money in their pockets (or in savings accounts earning 2 per cent interest), but are perpetually frustrated by the lack of material goods or even of good food and drink. The free markets for highquality vegetables and better-quality clothing in the large cities seem not to have dented this mismatch between the over-supply of money and the frustrated demand for goods.

Not that young people share this view. Their chief discontent is housing, or the general lack of it. Nominally, housing costs are low. A rented municipally owned apartment will cost a few rubles a month, the purchase of a share in a cooperative apartment block somewhere in excess of 1,200 rubles and a privately owned house (there are such things) ten times (or much more) as much.

The snags are that waiting lists for municipal apartments are several years long, at least in the major cities. The allocation systems are skewed in favour of party members and other dignitaries and even the apparently modest cost of cooperative apartments is beyond young people with only modest savings or with- 